\title{
New York spreads the news with $\$ 1.15$ billion biotech plan
}

New York has long been a leader in basic biomedical research and clinical care, but it is now making a big push to turn the city into a life-sciences hub and create some of the buzz that marks the established biotech centers of San Francisco and Boston. In December, the state announced a \$650-million injection in investment capital, tax incentives and financial grants for wet-lab space to attract new life-sciences startups. A day later, New York City unveiled a ten-year, $\$ 500$-million program to help young biotech companies hatch, stay and grow in the city. "We are really poised to catapult this city into a top-tier life sciences center," says Kathleen Warner, an executive vice president at the New York City Economic Development Corporation. "We have a unique mix - more so than Boston-of funding and academic medical centers, and an incredibly diverse demographic."

The surprise is that the city hasn't properly capitalized on those assets before, and therefore is now forced to play catch up. New York receives more funding from the National Institutes of Health- $\$ 1.4$ billion in 2016 - than any other metropolitan area other than Boston. It has a dense concentration of world-class academic and research centers, a booming healthcare sector, proximity to large pharmaceutical companies and plenty of cash. So why did biotech never take root in the Big Apple?

"What New York lacked was a place to put companies-there's a shortage of high-quality facilities here," says Carlo Rizzuto, partner at Versant Ventures of San Francisco, one of several venture capital firms now making a big bet on New York's biotech promise.

Another challenge has been the lack of local biopharma R\&D and management expertise, which makes it difficult to form and build companies. Nor does the city have a large-cap public biotech firm-akin to Genentech of S. San Francisco or Biogen of Boston-that can serve as an anchor to attract other firms or even spur spinoffs (Imclone was acquired by Indianapolis, Indianabased Eli Lilly in 2008).

"New York represents the greatest untapped biotech potential in the world. But for the city to become a biotech hub we need a landmark success - and probably more than one," says Jason Park of Flagship Pioneering in Cambridge, Massachusetts, another venture capital firm that has set up shop in New York.

The city has recently been bolstering its efforts. In 2010, it formed the Alexandria Center for Life Science, offering more than a million square feet of office and laboratory space. The facility opens its doors to startup biotech firms this May. Two years ago, New York City also launched a \$150-million funding program to support up to 20 life-sciences ventures (Nat. Biotechnol. 33, 1121, 2015).

In January, Johnson \& Johnson Innovation with New York State and the New York Genome Center announced plans for a project known as JLABS @ NYC. It is centered on a 30,000-square foot facility for up to 30 life sciences startups that will open next year in the Manhattan neighborhood of SoHo. Similar ventures have already been set up in London, San Francisco, S. San Francisco, Boston, Houston and Toronto.

Traditionally, the region has attracted little biotech activity. But the recent years' efforts by the city have heartened biotech venture capital firms, prompting several to set up shop in the area, including ARCH Venture Partners of Chicago, Accelerator of Seattle, and Deerfield Management and Apple Tree Partners, both

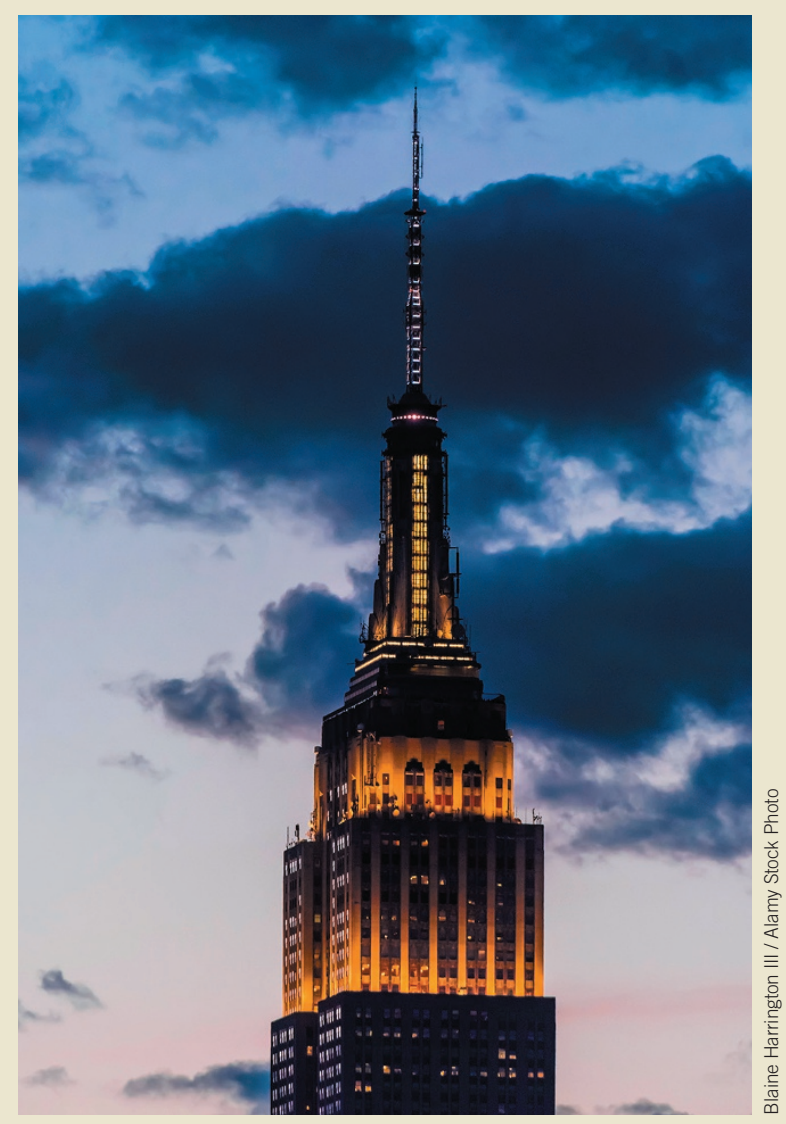

New York is in a biotech state of mind.

of New York. In 2015, Versant chose to set up its East Coast offices in New York instead of Boston because of what it considered to be the city's untapped biotech potential. In December 2016, Versant and Germany's pharma giant Bayer launched a stem-cell company BlueRock Therapeutics with a 'supergroup' of scientific founders in New York.

The research behind BlueRock emerged from Memorial Sloan Kettering Cancer Center in Manhattan. The scientists hope to use reprogrammed stem cells to treat cardiovascular, neurological and other types of conditions. To launch BlueRock, Versant and Bayer committed $\$ 225$ million-one of the biggest-ever series A financings for a biotech company. "Because a large chunk of the technology comes from Sloan Kettering, we chose to locate part of the company locally in order to stay close to the academic founders," says Rizzuto.

Both Rizzuto and Park of Flagship are emboldened by politicians' recent moves to ramp up funding and other initiatives to lay the groundwork for a full-fledged biotech industry in both the city and the state. But they both accept that the moves so far are mere baby steps.

"New York doesn't yet have a critical mass of people who have the experience and commitment to build and manage new biotech companies," says Park. "That will be fundamental to advance the promise."

Gautam Naik London 